\title{
The Analysis of Fourth Grade Primary Students' Reader Self-perceptions in Terms of Gender and Preschool Educational Background
}

\author{
Muhittin Sağırlı ${ }^{1}$, Burçin Okur ${ }^{2}$ \\ ${ }^{1}$ Ph.D., Asst. Prof., Hasan Ali Yücel Faculty of Education, Istanbul University, İstanbul, Turkey \\ ${ }^{2}$ Postgraduate, Institute of Educational Sciences, Marmara University, İstanbul, Turkey \\ Correspondence: Burçin Okur, Institute of Educational Sciences, Marmara University, İstanbul, Turkey.
}

Received: December 12, 2016

Accepted: December 23, 2016 Online Published: January 3, 2017

doi:10.11114/jets.v5i2.2062

URL:http://dx.doi.org/10.11114/jets.v5i2.2062

\begin{abstract}
The aim of this study was to analyse perceptions of fourth grade primary school students on their reading ability. In the study, screening model was used as a quantitative research method. The sample of this research was selected by convenience sampling. The sample consisted of 556 fourth grade students who received education in 8 public schools in 2014-2015 academic year in Tuzla, Pendik, Çekmeköy and Kadıköy districts, in İstanbul. A 'personal information form' and a 'Reading Self-Perception Scale' were used as data collection tools in this study. It is found that the readability level of scales and their sub-dimensions' was convenient for the research according to item analysis. The data collected by personal information form and Reader Self-Perception Scale was analysed with SPSS (Statistical Package for the Social Sciences) 23 statistical package program. For the analysis frequency and percentage distribution, mean square and standard deviation values, Kolmogorov-Smirnov test and independent samples t-test were used. The general reader self-perception of fourth graders is at positive level. The highest level of reader self-perceptions is at 'progress'. The general self-perception levels of students vary by gender. Also, the reader self-perceptions level of female students is higher than the reader self-perceptions level of male students. The reader self-perceptions of students vary by pre-school educational background. The students who have pre-school educational background have higher level of reader self-perception with its sub-dimensions than the students who don't have pre-school educational background.
\end{abstract}

Keywords: reading, reader self-perception, fourth grade, primary school

\section{Introduction}

Language is probably the most important instrument which enables people in expressing themselves and communicating. It has a significant role in cultural accumulation and development of humanity. It can be defined as a human-made system which consists of symbols and ensures communication (Stainthorp, 1989). Beside its communication function, language also enables obtaining cultural values of the society (İşeri, 2010). Listening, speaking, writing, reading and visual reading are the dimensions of language education. But perhaps the most essential dimension is reading. Reading skill alters the way of perception; ensures thinking in abstract categories and critical thinking (Sanders, 2013). Comprehending a text means that one has understood the basic information. So, the students who are insufficient in literacy skills are disconnected many dimensions of education (Pickett, 2005). Literacy skills are very significant not only in language lessons but also in other lessons. They are effective on school success in all grades (Öz \& Çelik, 2007). By reading people enrich their vocabulary, enlarge their imagination, broaden their horizons, develop their creativity and acquire new perspectives. But the level of these outcomes depends on environmental and individual differences (Akyol, 2008). It is important to note that the first literacy learning is very critical for children in the sense of reading in their life. In this period children learn reading the signs of written language and expressing themselves by writing. This period includes several skills from oral language to written language (Sağırlı, 2016).

There are two main groups of factors affecting reading comprehension. The first group includes factors related the text. Type, narrative organization, language, style (the length of sentences, metaphors, symbols etc.) and physical qualities (legibility, length of lines and font size etc.) are the parts of this group. The second group includes factors like preliminary knowledge about the text; interest, attention, vocabulary, reading purpose and reading motivation etc. (Sağırlı \& Ateş 2016). Reading is related to motivation and motivation is related to people's beliefs about themselves. These beliefs are defined as 'self-efficacy' in Social Cognitive Theory. Self-efficacy, is defined as "People's judgments 
of their capabilities to organize and execute courses of action required to attain designated types of performances" (Bandura, 1986). Self-efficacy doesn't mean the level of the competence; it means the perception about the level of competence (Gün\&Yıldız, 2014). The concept 'self-efficacy' came up during Bandura's therapies for phobic people. Bandura found out that people have individual differences on practicing the techniques because they had different perceptions about their practicing ability. Some of them couldn't conquer their fear even though they were volunteer to overcome. In other words, however they had same expectations and purposes, their perceptions about their competence caused the difference in the results. Bandura termed this situation as 'self-efficacy' (Zimmerman, 2000; Sakiz, 2013). There are four factors composing self-efficacy: performance accomplishments, vicarious experience, verbal persuasion and emotional arousal (Bandura, 1977). These factors are critical in explaining the term 'self-efficacy':

1. Performance accomplishments: This is the most efficient factor of the 4 factors (Bandura,1994). While successful performance experiences influence self-efficacy positively, unsuccessful experiences influence self-efficacy negatively (Arslan, 2012).

2. Vicarious experience: This factor expresses individual's indirect experiences which are obtained by social observation and comparison. Observing the successful people who are like oneself, increases the level of belief to be successful for similar activities (Bandura, 1977). Students observe their classmates and make judgements for themselves (Scott, 1996).

3. Verbal persuasion: This factor is about social feedback (Scott, 1996, p.199). Students are persuaded and encouraged by other people around them like their families, teachers and classmates (Scott, 1996). Constructive feedback has an impact on progress of self-efficacy.

4. Emotional arousal: This factor expresses physiological state, mood and stress level (Bandura, 1977). When students feel relaxed and safe, their self-efficacy is more likely to improve (Arslan, 2012).

Understanding these four factors enables teachers to create more useful learning environments (Henk, Marinak \& Melnick, 2012).

The level of self-efficacy can differ in various areas. For instance, a business man can have a high self-efficacy about his organizational skills and a low self-efficacy about his parenting competence (Bandura, 2006). Similarly, if a student has a low level of self-efficacy, his/ her probability of failure will increase. It is hard to have self-confidence for each subject. Teachers should prepare sufficient learning environments for each subject however good reading ability has positive impact on one's educational life (Akar, 2008). The people with high self-efficacy for reading, believe that they can perform well thus the reading materials around them attract their attention more. By means of this tendency, reading process begins. The reader activates his/ her prior knowledge by benefiting from the schematic form of the text. Then the reader combines his/ her prior knowledge with the knowledge of the text and makes an inference related to the meaning of the text (Ülper, 2011).

Reading self-efficacy is termed as "reading self-perception". Henk and Melnick developed "Reading Self-Perception Scale" to determine reading self-efficacy of individuals (Henk \& Melnick, 1995). The scale was adapted to Turkish and its validity and reliability study was done by Yaylı \& Duru (2008) for 4th and 5th graders. Reading self-perception can be defined as the positive or negative self-perceptions of reader about his/ her reading achievement (Baştuğ \& Çelik, 2015, p.905). If the teachers can evaluate and analyse self-perceptions of their students, they can effectively design learning experiences which respond to academic and emotional needs for reading (Wangsgard, 2014).

A review of literature shows that there are several studies on reading self-efficacy. Reading Self-Perception is examined in these studies under the following headings: a study of eighth graders' secondary school reading self-efficacy in terms of several variables (İnnal1, 2014), a study on eighth graders' reading self-efficacy in terms of some variables (İnnalı \& Aydın, 2014), the effect of sixth grade students' reading attitudes upon reading comprehension (Ünal, 2012), an examination of secondary school students' levels of reader self-perception in terms of gender, grade, reading environment and frequency (Baştuğ \& Çelik, 2015), parents' self-efficacy beliefs, parents' gender, children's reader self-perceptions, reading achievement and gender (Lynch, 2002), examining eighth grade students' reading self-efficacy (Uçgun, 2014), investigation of reading attitudes and self-perceptions of students reading on or below grade level (Hogsten \& Peregoy, 1999), the effects of the parent volunteer program upon students' self-perception as a reader (Adunyarittigun, 1997), reading self-efficacy and its effects upon literacy (Akar, 2008), a study on reading self-efficacy of secondary school students (K. Özturk, 2015), measuring the reader self-perceptions of adolescents (Henk, Marinak and Melnick, 2012), validity and reliability study on the scale of belief self-efficiency reading comprehension (Epçaçan \& Demirel, 2011), the adaptation of the reader self-perception scale to the fourth and fifth grade Turkish students (Yayl \& Duru, 2008), developing reader self-efficacy scale (Ülper, Yaylı and Karakaya, 2013),the adaptation of reader self-perception scale-2 into Turkish (Keskin \& Atmaca, 2014)... This study was hoped to make significant contribution to literature because it examines fourth grade students' reader self-perceptions with respect to their gender and 
preschool educational background. The previous studies generally analysed secondary school students' reader self-perceptions. The fourth grade is convenient for evaluating reader self-perceptions as it's the last grade in the primary level in Turkey. Also, the relationship between students' reading self-perceptions and their preschool educational factor hasn't been examined in previous studies. This study ought to answer the following questions:

1. What is the level of fourth graders' reader self-perceptions?

2. Does the students' level of reader self-perceptions differ depending on gender?

3. Does the students' level of reader self-perceptions differ depending on preschool educational background?

\section{Method}

\subsection{Research Design}

This study was carried out in screening model. In screening model, it is aimed to describe a past or present situation as it exists (Karasar, 2013).

\subsection{Study Group}

The study group consists of 556 fourth grade students who received education in 8 public primary schools in 2014-2015 academic year in Tuzla, Pendik, Çekmeköy and Kadıköy districts in İstanbul. Demographic/ personal information of study group is summarized on Table 1 . The sample of this research was selected by convenience sampling. In convenience sampling, easily reachable elements are selected (Özen \& Gül, 2007).

Table 1. Distribution about Personal Information of Study Group

\begin{tabular}{llll}
\hline Variable & Group & $f$ & $\%$ \\
\hline Gender & Female & 310 & 55,8 \\
& Male & 246 & 44,2 \\
P.E. Background & Yes & 282 & 50,7 \\
& No & 274 & 49,3 \\
Total & & 556 & 100 \\
\hline
\end{tabular}

\subsection{Data Collection Instruments}

\subsubsection{Data Collection}

A 'Personal information form' and The Reading Self-Perception Scale were used as data collection tools in the study. The personal information form was prepared by researcher to obtain information about the gender of the students and whether the students received preschool education or not. The Reading Self-Perception Scale was developed by Henk \& Melnick (1995) and it was adapted to Turkish, its validity and reliability study was done by Yaylı \& Duru (2008) for 4th and 5 th graders. The scale consists of 5 dimensions and 31 items. According to validity and readability study which was made by Yaylı \& Duru (2008) with 629 students, it was found that five factor structure of the scale explains \%51,98 of total variance. Reliability co-efficient of the scale's sub-dimensions was accounted: progress $\alpha=.80$, physiological states $\alpha=.83$, social feedback from friends and teacher $\alpha=.85$, observational comparison $\alpha=.79$, social feedback from family $\alpha=.74$ (Yaylı \& Duru, 2008, p.199). Convenience of Self-Perception Scale for this study was analysed by viewing readability factors again with item analysis. It was found that the level of scales and their sub-dimensions' readability are convenient for the research according to item analysis. The results are presented on Table 2.

Table 2. The Readability Analyse of Reader Self-Perception Scale

\begin{tabular}{lll}
\hline Dimensions/Scale & Items & $\alpha$ \\
\hline Progress (9 items) & $9,12,13,16,17,21,22,25,26$ & 0,881 \\
Physiological States (7 items) & $7,14,19,23,24,27,30$ & 0,861 \\
Social Feedback from Friends and Teacher (6 items) & $2,3,6,8,15,28$ & 0,812 \\
Observational Comparison (5 items) & $4,5,10,18,20$ & 0,745 \\
Social Feedback from Family (3 items) & $11,29,31$ & 0,748 \\
Reader Self-Perception Scale (31 items) & & 0,934 \\
\hline
\end{tabular}

\subsubsection{Data Analyse}

All the data which were collected by personal information form and reader self-perception scale were analysed by SPSS (Statistical Package for the Social Sciences) 23 statistical package program. Before analyse, the data was controlled related errors, missing and normality distribution. After the control by Kolmogorov-Smirnov (K-S) analyse, the tests which will be implemented (parametric or non-parametric) were chosen. Distribution of the scores have normality in gender and preschool educational background variables $(p>0,05)$. " $p>05$ " is criterion for the normality of data group (Pallant, 2005). The results of normality distribution control are summarized on Table 3. 
Table 3. Kolmogorov-Smirnov Test Results of Reader Self-Perception Scale and Its Sub-Dimensions

\begin{tabular}{lll}
\hline & Independent Variables & \\
\cline { 2 - 3 } Dependent Variables & Gender & $\begin{array}{l}\text { Preschool Educational } \\
\text { Background }\end{array}$ \\
\hline Progress & $\mathrm{p}=0,133$ & $\mathrm{p}=0,184$ \\
Physiological states & $\mathrm{p}=0,204$ & $\mathrm{p}=0,112$ \\
Social feedback from friends and teacher & $\mathrm{p}=0,282$ & $\mathrm{p}=0,156$ \\
Observational comparison & $\mathrm{p}=0,270$ & $\mathrm{p}=0,163$ \\
Social feedback from family & $\mathrm{p}=0,165$ & $\mathrm{p}=0,140$ \\
Total reader self-perception & $\mathrm{p}=0,196$ & $\mathrm{p}=0,172$ \\
\hline
\end{tabular}

After the Kolmogorov-Sminov Test, percentage and frequency for personal information; mean and standard deviation for general scores of scales and its sub-dimensions, independent samples t-test for differentiation according to gender and preschool educational background were calculated. In all statistics calculation significance level was accepted as ".05". When significance level was found as less than $.05(\mathrm{p}<.05)$ it was accepted that there's a differentiation/ relationship between the groups and the assessment was made accordingly.

\section{Results}

The descriptive statistics of students' reader self-perceptions are shown on Table 4. The difference in reader self-perception level by gender and by independent samples t- test, is shown on Table 5. The differentiation of reader self-perception level with respect to preschool educational background by independent samples t-test is shown on Table 6.

Table 4. Descriptive Statics about the Level of Fourth Graders' Reader Self-Perceptions

\begin{tabular}{lcc}
\hline Dimension & $\bar{X}$ & SD \\
\hline Progress & 4,21 & 0,81 \\
Physiological States & 4,18 & 0,81 \\
Social Feedback from Friends and Teacher & 3,53 & 0,74 \\
Observational Comparison & 3,52 & 0,75 \\
Social Feedback from Family & 3,92 & 0,90 \\
Total Reader Self-Perception & 3,87 & 0,64 \\
\hline
\end{tabular}

As it is seen on Table 4, reader self-perception level of participant students is between 3,52 $\pm 0,75$ and 4,21 $\pm 0,81$. Mean score of students' general reader self-perception level was accounted as $3,87 \pm 0,64$. The general self-perception level of students is at positive level. The highest level of self-perceptions is at 'progress' dimension $(4,21 \pm 0,81)$. 'Physiological states' $(4,18 \pm 0,81)$, 'social feedback from family' $(3,92 \pm 0,90)$, 'social feedback from friends and teacher' $(3,53 \pm 0,74)$, and 'observational comparison' $(3,52 \pm 0,75)$ dimensions follow level of 'progress' dimension in a row.

Table 5. Independent Samples t-Test Results About Differentiation of Reader Fourth Graders' Self-Perceptions Level with respect to Gender

\begin{tabular}{|c|c|c|c|c|c|c|c|}
\hline \multirow{2}{*}{ Dimension/Scale } & \multirow{2}{*}{ Gender } & \multicolumn{3}{|c|}{ Descriptive Statistics } & \multicolumn{3}{|c|}{ t-test } \\
\hline & & $\mathrm{N}$ & $X$ & SD & $\mathrm{t}$ & df & $\mathrm{P}$ \\
\hline \multirow[t]{2}{*}{ Progress } & Female & 310 & 4,25 & 0,81 & 1,18 & 554 & 0,237 \\
\hline & Male & 246 & 4,17 & 0,81 & & & \\
\hline \multirow[t]{2}{*}{ Physiological States } & Female & 310 & 4,29 & 0,82 & 3,59 & 554 & $0,000 * *$ \\
\hline & Male & 246 & 4,04 & 0,78 & & & \\
\hline \multirow{2}{*}{$\begin{array}{l}\text { Social Feedback from Friends and } \\
\text { Teacher }\end{array}$} & Female & 310 & 3,62 & 0,76 & 3,21 & 554 & $0,001 *$ \\
\hline & Male & 246 & 3,42 & 0,69 & & & \\
\hline \multirow[t]{2}{*}{ Observational Comparison } & Female & 310 & 3,57 & 0,73 & 1,63 & 554 & 0,104 \\
\hline & Male & 246 & 3,46 & 0,77 & & & \\
\hline \multirow[t]{2}{*}{ Social Feedback from Family } & Female & 310 & 4,02 & 0,89 & 2,84 & 554 & $0,005^{*}$ \\
\hline & Male & 246 & 3,80 & 0,91 & & & \\
\hline \multirow[t]{2}{*}{ Total Reader Self-Perception } & Female & 310 & 3,95 & 0,64 & 3,14 & 554 & $0,002 *$ \\
\hline & Male & 246 & 3,78 & 0,62 & & & \\
\hline
\end{tabular}

As it seen on Table 5. there's a significant difference between female and male students' reader self-percentions level $\left[\mathrm{t}_{(554)}=3,14\right.$ and $\left.\mathrm{p}<, 05\right]$. Female students' general mean score is higher than male students' $\left(\bar{X}_{\text {Female }}=3,95\right.$ and $\bar{X}$ $\mathrm{M}_{\mathrm{all}}=3.78$ ). Level of 'progress' dimension doesn't varv bv gender. Female students' level of 'progress' is higher than male students' ( $\bar{X}_{\text {Female }}=4,25$ and $\bar{X}_{\text {Male }}=4,17$ ), but there's not a significant difference $(\mathrm{p}>0,05)$. Level of 'observational comparison' dimension doesn't vary bv gender too. Female students' level of 'observational comparison' is higher than male students' ( $\bar{X}_{\text {Female }}=3,57$ and $\left.\bar{X}_{\text {Male }}=3,46\right)$, but there's not a significant difference again ( $\left.p>0,05\right)$. Level of 'phvsiological states' varies bv gender in favor of female students $\Gamma_{t_{\varsigma} \varsigma \Lambda}=3.59$ and $\mathfrak{b}<.0011$. When the mean score is reviewed, female students' level of 'physiological states' is higher than male students' ( $\bar{X}_{\text {Female }}=4,29$ and $\bar{X}$ Male $=4,04)$. Level of 'social feedback from friends and teacher' $\left[\mathrm{t}_{(554)}=3,21\right.$ and $\left.\mathrm{p}<, 05\right]$ and level of 'social feedback from 
familv' $\left\lceil\mathrm{t}_{\ulcorner\ulcorner 54}=2.84\right.$ and $\left.\mathrm{p}<.05\right\rceil$ varv by gender in favor of female students too. When the mean scores are reviewed. female students' levels of 'social feedback from friends and teacher' $\left(\bar{X}_{\text {Famalo }}=3.62\right.$ and $\left.\bar{X}_{\text {Male }}=3,42\right)$ and 'social feedback from family' ( $\bar{X}_{\text {Female }}=4,02$ and $\bar{X}_{\text {Male }}=3,80$ ) are higher than male students'.

Table 6. Independent samples t-test results about differentiation of fourth graders' reader self-perceptions level with respect to preschool educational background

\begin{tabular}{|c|c|c|c|c|c|c|c|}
\hline \multirow{2}{*}{ Dimension/Scale } & \multirow{2}{*}{$\begin{array}{l}\text { P. } \\
\text { Background }\end{array}$} & \multicolumn{3}{|c|}{ E. Descriptive Statistics } & \multicolumn{3}{|l|}{ t-test } \\
\hline & & $\mathrm{N}$ & $\bar{X}$ & SD & $\mathrm{T}$ & $\mathrm{df}$ & $\mathrm{P}$ \\
\hline \multirow[t]{2}{*}{ Progress } & Yes & 282 & 4,33 & 0,75 & 3,43 & 554 & $0,001^{*}$ \\
\hline & No & 274 & 4,09 & 0,85 & & & \\
\hline \multirow[t]{2}{*}{ Physiological States } & Yes & 282 & 4,29 & 0,76 & 3,26 & 554 & $0,001 *$ \\
\hline & No & 274 & 4,06 & 0,84 & & & \\
\hline Social Feedback from Friends and & Yes & 282 & 3,61 & 0,77 & 2,61 & 554 & $0,009 *$ \\
\hline Teacher & No & 274 & 3,45 & 0,69 & & & \\
\hline \multirow[t]{2}{*}{ Observational Comparison } & Yes & 282 & 3,62 & 0,75 & 3,23 & 554 & $0,001 *$ \\
\hline & No & 274 & 3,42 & 0,73 & & & \\
\hline \multirow[t]{2}{*}{ Social Feedback from Family } & Yes & 282 & 4,09 & 0,86 & 4,37 & 554 & $0,000 * *$ \\
\hline & No & 274 & 3,76 & 0,91 & & & \\
\hline \multirow[t]{2}{*}{ Total Reader Self-Perception } & Yes & 282 & 3,99 & 0,62 & 4,32 & 554 & $0,000 * *$ \\
\hline & No & 274 & 3,76 & 0,64 & & & \\
\hline
\end{tabular}

As it seen on Table 6, there's a significant difference in students' reader self-perceptions level according to preschool educational background in favor of the students who have preschool educational background $\mathrm{t}_{(554)}=4.32$ and $\mathrm{p}<.0011$. In all sub-dimensions the students who have preschool background have higher mean scores: 'progress' ( $\bar{X}_{\text {vas }}=4.33$ and $\left.\bar{X}_{\mathrm{Nn}}=4.09\right)$. 'phvsiological states' $\left(\bar{X}_{\mathrm{vac}}=4.29\right.$ and $\left.\bar{X}_{\mathrm{N} n}=4.06\right)$. 'social feedback from friens and teacher' $(\bar{X}$ $\mathrm{v}_{\mathrm{cc}}=3.61$ and $\left.\bar{X}_{\mathrm{Nn}}=3.45\right)$. 'observational comparison' ( $\bar{X}_{\mathrm{v}_{\mathrm{cc}}}=3.62$ and $\left.\bar{X}_{\mathrm{N} n}=3.42\right)$ and 'social feedback from familv' ( $\bar{X}_{\text {Yes }}=4,09$ and $\bar{X}_{\text {No }}=3,76$ ). There's a significant difference in all sub-dimensions in favor of students who have preschool educational background too: 'progress' $\left[\mathrm{t}_{(554)}=3,43\right.$ and $\left.\mathrm{p}<, 05\right]$, 'phsiological states' $\left[\mathrm{t}_{(554)}=3,26\right.$ and $\left.\mathrm{p}<, 05\right]$, 'social feedback from friends and teacher' $\left[\mathrm{t}_{(554)}=2,61\right.$ and $\left.\mathrm{p}<, 05\right]$, 'observational comparison' $\left[\mathrm{t}_{(554)}=3,23\right.$ and $\left.\mathrm{p}<, 05\right]$, 'social feedback from family' $\left[\mathrm{t}_{(554)}=4,37\right.$ and $\left.\mathrm{p}<, 001\right]$.

\section{Conclusion, Discussion and Recommendations}

The results of present study conducted to determine reader self-perceptions of fourth graders' in terms of gender and preschool educational background. It was found that reader self-perceptions of fourth graders' is at a positive level. The highest level of reader self-perceptions is at 'progress' dimension. 'Physiological states', 'social feedback from family', 'social feedback from friends and teacher' and 'observational comparison' dimensions follow level of 'progress' dimension in a row. Some researches in the literature have overlapping results. İnnalı \& Aydın (2014) analysed eighth grade students' reader self-efficacy and they determined that students assessed themselves as 'good readers'. Uçgun (2014) analysed eighth graders' self-efficacy too. And the researcher reached that the students believe that their reading performance is at good level. Some researches' results don't correspond with results of this study. Ünal (2012) analysed the effect of sixth grade students' reading attitudes upon reading comprehension and the researcher found that students' reading self-effiacy level is not at sufficient level. Baştuğ \& Çelik (2015) found that secondary education students' reader self-perceptions aren't at good level. In that research, it was found that, students' 'progress' scores are at over middle level, 'observational comparison' scores are at middle level, 'social feedback' and 'physiological states' scores are at low level. It can be said that more researches are needed in primary grade in this field.

In this current research, it was found that the reader self-perceptions level of female students is higher than the reader self-perceptions level of male students. When the levels of 'progress' and 'observational comparison' of students don't vary by gender, female students' levels of 'physiological states', 'social feedback from friends and teacher' and 'social feedback from family' dimensions are higher than male students' levels. Yayl \& Duru (2008) found that reader self-perceptions of fourth and fifth grade female students are higher than male students' as a result of their study which was aimed to adapt 'Reader Self-Perception Scale' to Turkish. There are more supportive results in the literature. Lynch (2002) analysed the reader self-perceptions of 8-9 years old students and found that reader self-perception 'social feedback' dimension level of girls is higher than boys'. Also, level of reading attitude and reading test scores are higher than boys'. Baştuğ \& Çelik (2015), İnnalı \& Aydın (2014) and Uçgun (2014) found that reader self-perception level varies by gender in favor of girls. Ünal (2012) found that reading attitude scores of girls are higher than boys' and girls' spend more time to reading than boys. İzci (2013) analysed the relationship between reading attitudes and achievement in using punctuation marks of fifth grade students and it was found that reading attitude level of girls is higher than boys'. Hogsten \& Peregoy (1999) found that reading attitude level of girls is higher than boys' too. However most of the results have similar results, there are divergent results in the literature. Karakoç Öztürk (2015) researched secondary school students' reading self-efficacy and found that it doesn't vary by gender. 
In this research, it was found that the reader self-perceptions of students with its sub-dimensions (progress, physiological states, social feedback from friends and teacher, observational comparison, social feedback from family) vary by pre-school educational background. The students who have preschool educational background have higher level of reader self-perception with its sub-dimensions than the students who don't have preschool educational background. Yılmaz \& D. Sığırtmaç (2008) found that the students who have preschool educational background, reached literacy earlier than other students at first grade. Erkan \& Kirca (2010) determined that students who have preschool educational background have higher readiness level than others'. Arslan (2009) compared the reading and listening skills level of second grade students who have preschool educational background and who don't. The researcher reached that the students who have preschool educational background are more successful than others. Taner \& Başal (2005) analysed first graders' language development and found that students who have preschool educational background are at better level in language development. Özenç \& Așıcı (2012) found that fifth grade students who have preschool educational background are more skilled in functional literacy than the students who don't have preschool educational background.

There are some strategies to develop student's self-efficacy at schools. Teachers should give feedback not only to effort but also to skills. It can be harmful to compare students when giving feedback. When giving tasks, principle of progressivity should be considered and teachers should start from simple tasks before hard ones. When starting new subjects, old experiences should be reminded. In learning environments, control of the lesson should be left to students under suitable conditions. Students should be motivated to develop their own learning strategies and to be assisted to prefer appropriate strategies. It can be beneficial to help students but this support is supposed to be limited. Teachers ought to help the students to gain reading habit and joy of reading (Sakız, 2013, s.195-201).

At schools, it's important to organize activities which help students to have positive relationship with reading. The reading activities which help students to make oral reading practices should be arranged. The group technics which help students to observe good readers should be set. Teachers should prefer using positive language when giving feedback about reading activities. Teachers should teach students to give each other constructive feedback during these activities. Families should be encouraged to give positive feedback to their children about their reading by teachers. It's significant to ensure qualified materials and appropriate environments in developing reading self-perception (Henk \& Melnick, 1995; Wangsgard, 2014).

It is important to determine students' reader self-perceptions before organizing reading activities. But it is more beneficial focusing not only general reader self-perceptions but also sub-dimensions because students are influenced from various situations. The reader self-perceptions level of female students is higher than level of male students. This should be considered when forming the reading contexts and more attractive subjects for boys should be included. More researches should be organized to determine the reasons of varying in gender about reader self-perceptions. The students who have pre-school educational background have higher level of reader self-perception than the students who don't have preschool educational background. This finding highlights the importance of the preschool education for reading. This research was studied by quantitative method. More researches can be made in qualitative method to get more detailed and causative inferences.

\section{References}

Adunyarittigun, D. (1997). Effects of the parent volunteer program upon students' self-perception as a reader. (Report No. CS012713). University of Maryland College Park. (ERIC Document Reproduction Service No. ED404617).

Akar, C. (2008). Self-Efficacy Beliefs and Its Effects of Reading and Writing. Journal of Uşak University Social Sciences, 1(2), 185-198.

Akyol, H. (2008). Turkish Teaching Methods. Ankara: Kök Press.

Arslan, A. (2009). The Differences about Understanding Training the Second Class Students Who Attended and Notattended Education of Preschool. Ekev Acedemic Rewiev, 40, 1-11.

Arslan, A. (2012). Predictive Power of the Sources of Primary School Students' Self-efficacy Beliefs on Their Self-efficacy Beliefs for Learning and Performance. Educational Sciences: Theory \& Practice, 12(3), 1907-1920.

Bandura, A. (1977). Toward a unifying theory of behavioral change. Psychological Review, 84(2), 191-215. https://doi.org/10.1037/0033-295X.84.2.191

Bandura, A. (1986). Social foundations of thought and action: A social cognitive theory. Englewood Cliffs, NJ: Prentice Hall.

Bandura, A. (1994). Self-efficacy. In V. S. Ramachaudran (Ed.), Encyclopedia of Human Behaviour (Vol 4, pp.71-81). Newyork Academic Press.

Bandura, A. (2006). Guide for constructing self-efficacy scales. In F. Pajares ve T. Urdan (Eds.), Self-efficacy beliefs of 
adolescents (pp.307-337). Greenwich, CT: Information Age Publishing.

Baştuğ, M., \& Çelik, T. (2015). An Examination of Secondary School Students' Levels of Reader Self-Perception in Terms of Gender, Grade, Reading Environment and Frequency. International Journal of Human Sciences, 12(1), 903-918. https://doi.org/10.14687/ijhs.v12i1.3120

Epçaçan, C., \& Demirel, Ö. (2011). Validity and Reliability Study on the Scale of Belief Self-Efficiency Reading Compherension. The Journal of International Social Research, 4(16), 120-128.

Gün, E., \& Yıldız, G. (2014). Development of Self-Efficacy Scale of Piano Performance towards the Pre-Service Music Teacher. Turkish Studies-International Periodical for the Languages, Literature and History of Turkish or Turkic, 9(5), 1053-1065. https://doi.org/10.7827/turkishstudies.6896

Henk, W. A., \& Melnick, S. A. (1995). The reader self-perception scale (RSPS): A new tool for measuring how children feel about themselves as readers. The Reading Teacher, 48(6), 470-482.

Henk, W. A., Marinak, B. A., \& Melnick, S. A. (2012). Measuring the Reader Self Perceptions of Adolescents In Troducing The Rsps2. Journal of Adolescent \& Adult Literacy, 56(4), 311-320. https://doi.org/10.1002/JAAL.00144

Hogsten, J. F., \& Peregoy, P. A. (1999). An investigation of reading attitudes and self-perceptions of students reading on or below grade level: Research report. (ERIC Document Reproduction Service No. ED 448432). Charlottesville, VA: University of Virginia.

İnnalı, H. Ö. (2014). A Study on 8th Graders' Reading Self-Efficacy in Terms of Some Variables. Unpublished Master's Thesis, Dokuz Eylül University, İzmir.

İnnalı, H. Ö., \& Aydın, İ. S. (2014). A Study on 8th Graders' Reading Self-Efficacy in Terms of Some Variables. Turkish Studies, 9(9), 651-682. https://doi.org/10.7827/TurkishStudies.7132

İşeri, K. (2010). The Investigation of the Reading Attitudes of Second Grade Students. International Journal of Human Sciences, 7(2), 468-487.

İzci, G. (2013). The Examintion Between the Students'Achievements in Using Punctiation Marks and Their Attitudes towards Reading. Unpublished Master's Thesis, Akdeniz University, Antalya.

Karakoç, Ö. B. (2015). A Study on Reading Self-Efficacy of Secondary School Students: Adana City Example. Journal of Adiyaman University Social Sciences Institute, 21, 909-935.

Karasar, N. (2013). Bilimsel Araştırma Yöntemi. Ankara: Anı.

Keskin, H. K., \& Atmaca, T. (2014). The Adaptation of Reader Self-Perception Scale-2 into Turkish (RSPS-2). Elementary Education Online, 13(1), 306-318.

Lynch, J. (2002). Parents' self-efficacy beliefs, parents' gender, children's reader self-perceptions, reading achievement and gender. Journal of Research in Reading, 25(1), 54-67. https://doi.org/10.1111/1467-9817.00158

Öz, F., \& Çelik, K. (2007). Practical Literacy Teaching. Ankara: Anı.

Özen, Y., \& Gül, A. (2007). Population-Sampling Issue on Social and Educational Research Studies. Journal Kazım Karabekir Educational Faculty, 15, 395-422.

Özenç, E. G., \& Aşıcı, M. (2012). The Examination of Fifth Grade Primary Students Functional Literacy Levels' According to Different Variables. Journal of Uludag University Educational Faculty, 25(2), 547-572.

Pallant, J. (2005). SPSS survival manual: a step by step guide to data analysis using SPSS for windows (Version 12). Maidenhead: Open University Press.

Pickett, L. (2005). Potential for play in a primary literacy curriculum. Journal of Early Childhood Teacher Education, 25, 267-274. https://doi.org/10.1080/1090102050250310

Sağırlı, M. (2016). Analysis of Reading Comprehension Levels of Fifth Grade Students Who Learned to Read and Write with the Sentence Method. Journal of Education and Training Studies, 4(2), 105-112.

Sağırlı, M., \& Kadığlu, A. H. (2016). A Research on Reading Comprehension Levels of Fifth-Grade Students Who Learned to Read and Write for the First Time with Sound-Based Sentence Method. Journal of Education and Training Studies, 4(3), 63-71.

Sakız, G. (2013). Key Word in Success: Self-efficacy. Journal of Uludag University Educational Faculty, 26(1), 185-209.

Sanders, B. (2013). A is for Ox The Collapse of Literacy and the Rise of Violence in an Electronic Age . (Ş. Tahir, 
Translation). İstanbul: Ayrıntı Press.

Scott, J. E. (1996). Self-Efficacy: A Key to Literacy Learning. Reading Horizons, 36(3), 195-213.

Stainthorp, R. (1989). Practical psychology for primary teachers. London: The Falmer Press.

Taner, M., \& Başal, A. (2005). Compare Language Development in First Grade Primary School Students from Different Socioeconomic Levels Who Take and not Take Pre-School Education According to Gender. Journal of Uludag University Educational Faculty, (2), 395-420.

Uçgun, D. (2014). Examining $8^{\text {th }}$ Grade Students' Reading Self-Efficacy: Sample of Nigde. International Journal of Language Academy, 2(2), 38-47. https://doi.org/10.18033/ijla.90

Ülper, H. (2011).The motivational Factors for Reading in Terms of Students. Educational Sciences: Theory \& Practice, 11(2), 941-960.

Ülper, H., Yayl1, D., \& Karakaya, İ. (2013). Developing the Reader Self-Efficacy Scale. Ahi Evran University Journal of Kırşehir Educational Faculty (KEFAD), 14(1), 85-100.

Ünal, M. (2012). The Effect of $6^{\text {th }}$ Grade Students' Reading Attitudes upon Reading Comprehension. Unpublished Master's Thesis. Ondokuz Mayıs University, Samsun.

Wangsgard, N. (2014). "Am I a Good Reader?" A Friendly Way to Evaluate Students Perceptions' of Themselves as a Reader. Reading Improvement, 51(1), 4-10.

Yayli, D., \& Duru, E. (2008). The Adaptation of the Reader Self-Perception Scale to the $4^{\text {th }}$ and $5^{\text {th }}$ Grade Turkish Students. Eurasian Journal of Educational Research, 33, 193-210.

Yllmaz, E., \& Dikici, S. A. (2008). The Investigation of Transition Times to the First Reading and Writing in $1^{\text {st }}$ Class Primary School Student According to Attend or not Attend Pre-school Education. Contemporary Education Journal, 349, 30-36.

Zimmerman, B. J. (2000). Self-Efficacy: An Essential Motive to Learn. Contemporary Educational Psychology, 25, 82-91. https://doi.org/10.1006/ceps.1999.1016

\section{Copyrights}

Copyright for this article is retained by the author(s), with first publication rights granted to the journal.

This is an open-access article distributed under the terms and conditions of the Creative Commons Attribution license which permits unrestricted use, distribution, and reproduction in any medium, provided the original work is properly cited. 